811.163.41'28:001.4

371.26-057.874

https://doi.org/10.18485/sj.2017.22.1.7

МИХАИЛО М. ШЋЕПАНОВИЪ *

Универзитет у Београду

Филолошки факултет
Оригинални научни рад

Примљен: 04. 08. 2016.

Прихваћен: 15. 12. 2016.

\title{
СРПСКА ДИЈАЛЕКТОЛОШКА ТЕРМИНОЛОГИЈА И НАСТАВНА ПРАКСА
}

\begin{abstract}
Одавно постоји неуједначеност у коришћењу српске дијалектолошке терминологије у научној, стручној и наставној пракси на целом српском језичком простору. Од решавања тог проблема зависи пре свега могућност усвајања немалог броја дијалектолошких садржаја на различитим нивоима образовања, а посебно у основношколској и средњошколској настави. Циљ рада је да се установи у којој мери су ученици основне школе и средњих школа овладали основним дијалектолошким терминима. Узорак истраживања је пригодан и чини га 315 ученика основних и средњих школа у Београду, Новом Саду, Нишу, Крагујевцу и Крушевцу. За потребе овог истраживања конципиран је упитник који је садржао питања отвореног типа. У обради података коришћена је дескриптивна статистичка анализа, Хи-квадрат тест, док је у неким сегментима анализе употребљен Пирсонов коефицијент корелације. Резултати истраживања показују да је на сва питања тачно одговорило само двоје ученика, док је на питања која се тичу дефинисања термина дијалекат и наречје (двају основних термина у дијалектологији) тачно одговорило мање од половине, односно мање од четвртине ученика. Резултати испитивања указују на чињеницу да је конфузија из средњошколских и основношколских граматика, које су до сада биле у употреби, произвела конфузију у садашњој наставној пракси. Стога се у раду, на основу проведене анализе, даје коментар досадашњих терминолошких решења у српској дијалектологији и њихове примене у граматичкој литерату-
\end{abstract}

*mihail.scepanovic@gmail.com 
ри и наставној пракси, с посебним освртом на номенклатурни низ: дијалекат - наречје - говорни тип - говор - идиолекат - и даје се систематичнији приступ резрешавању овог проблема.

Кључне речи: дијалектологија, терминологија, наставна пракса, дијалекат, наречје, ученици.

\section{УВОД}

Премда је основни циљ наставе српског језика, како у основној тако и у средњој школи, да ученици овладају законитостима српског књижевног језика на којем ће се усмено и писано правилно изражавати, без упоређивања дијалекта, на чијем се подручју изводи настава, са књижевним језиком и његовим законитостима, настава српског језика не може бити у потпуности успешна, нити ученици могу на сврсисходан начин усвојити експлицитну норму. С тим у вези, „ни један говор, ма колико био удаљен од књижевног, наставник не смије да посматра као израз ниже комуникативне вриједности... јер се не може говорити о добрим и лошим дијалектима, већ о онима који су ближи књижевном језику и онима који су удаљенији од њега” (Ћупић, 2001: 347). Заправо, реализација примарних задатака наставе српског језика биће остварена само ако се не занемари језичко знање и умење које је ученик понео из породице и из средине која га окружује, односно уколико наставник покаже ученицима које језичке појаве - чије су особености карактеристика одређеног дијалекатског подручја - одступају од књижевног језика.

Разматрајући актуелне наставне програме за српски језик, опажамо да се ученици први пут упознају са основним терминима из дијалектологије у осмом разреду основне школе (Службени гласник РС, Просветни гласник, 72/9). У оквиру наставе граматике издвојени су садржаји под насловом: Српски језик међу другим словенским језицима, Дијалекти српског језика, Народни језик (језик као скуп дијалеката) и књижевни језик. Притом, ни поред једног поменутог наставног садржаја нису дата опсежнија објашњења нити упутства која се тичу његове реализације. Ипак, приређивачи програма су предвидели да би само у вези са темом Дијалекти српског језика током наставе требало да буду образложени искључиво основни подаци, не прецизирајући у ком обиму. Дакле, након завршене основне школе ученици ће научити или ће бити упознати само са појединим елементарним појмовима из дијалектолошке науке.

Увидом у важеће наставне програме за српски језик за средње стручне школе и гимназије ${ }^{1}$ уочавамо да је одређеним питањима из дијалектологије

\footnotetext{
${ }^{1}$ Независно од тога да ли је у питању гимназија (сви смерови) или средња стручна школа садржај наставног програма је исти. Разлика је направљена само у броју часова предвиђених за реализовање наставе српског језика и књижевности.
} 
посвећено нешто више пажње (Службени Гласнк РС - Просветни гласник, 5/1990; 3/1991; 4/1991). Наиме, у првом и другом разреду би ученици требало да изучавају следеће теме из дијалектологије: језик, дијалект и социолект, нестандардни језички варијетети, наречја српског језика (критеријуми, подела, називи, размештај, основне особине), дијалекатска основица српског књижевног језика, екавски и ијекавски изговор. На основу изложеног, опажамо да приређивачи програма подразумевају да су ученици овладали основним знањем из дијалектологије и предвиђају да би у средњој школи требало научено допунити, проширити и доградити новим појмовима и терминима. Међутим, анализа датих програма показује и да се, на пример, термин наречје први пут помиње у првом разреду средње школе.

Уколико имамо у виду чињеницу да се настава српског језика у средњој школи неретко потискује зарад наставе књижевности (Ковачевић 2014), мало је вероватно да ће ученици овладати основним терминима и темама из дијалектолошке науке. Штавише, резултати бројних истраживања упућују на то да ученици у Србији завршавају формално и факултетско образовање недовољно функционално писмени и опскрбљени адекватним знањем из српског језика које ће применити у свакодневним формалним или неформалним језичким ситуацијама (Петровачки, 1997; Драгићевић, 2006; Јањић, 2008; Чутура и сар., 2009; Ковачевић, 2012; Ковачевић, 2014).

Чињеницу да у нашој школској пракси уџбеник, заправо, представља „операционализовани школски програм” (Ивић и сар., 2003: 9), односно да је један од императивних захтева при изради уџбеника „да 'покрива' школски програм у целини" (Ивић и сар., 2009: 23) потврђује анализа заступљених тема, које се односе на дијалектолошку науку, у уџбеницима за основну и средњу школу. У основношколској уџбеничкој литератури (Ломпар 2010; Добрић и др. 2011; Ћећез-Иљукић и др. 2010) обрађене су све, програмом предвиђене, наставне јединице из дијалектологије. Притом, у појединим уџбеницима су дате тематске целине опсежније објашњене, док су у другим одређене теме остале на маргини. Дефинисање основних дијалекатских термина, као што je, на пример, одређивање појма наречје - није дато у свим, за ову прилику, анализираним уџбеницима. Сажимање и сужавање основних дијалектолошких тема присутно је и у уџбенику Ж. Станојчића за гимназије и средње школе (Станојчић, 2010), као и у коауторској граматици за гимназије и средње школе (Станојчић, Поповић, 2011). Дакле, усклађеност уџбеничке литературе са наставним програмима не подразумева увек њихову потпуну ефикасност, што се јасно уочава и када се разматра наставна материја из дијалектологије. Нити у програму, у оквиру наставних интерпретација, нити у датим граматикама није експлицитно образложен искључујући хијерархијски статус појединих термина, и то оних темељних какви су наречје и дијалекат. Преглед уџбеничких садржаја указује на низ недоследности, што код ученика може изазвати сумње, 
пометње а последично и незаинтересованост за недовољно јасно изложену материју из дијалектологије.

Имајући у виду тему рада, сматрамо да је потребно појаснити основне школске дијалектолошке термине. У лингвистичкој литератури се под термином дијалекат обично означава органски идиом који је опозиционо сучељен термину стандардни, односно књижевни језик - који се сматра неорганским идиомом. Настао спојем деловања саме унутарјезичке еволуције и на њој одражених културноисторијских факата одређене територијалне стварности, дијалекат је основно исходиште органског развитка самог језика. У научностручним радовима наших дијалектолога се уз овај термин, који је као европеизам грчког порекла, користи преведени термин говор, тако да се отуда јавља у литератури лепеза шаренила, непрецизности и нејасноћа при именовању, по обиму различитих територијалних реализација. Већ сама чињеница да се термин говор у лингвистици, с једне стране користи као синоним за дијалекат, a с друге стране има општелингвистичко значење материјализације језика као апстрактног система (у структуралној дистинкцији језик: говор), није чудно што долази до терминолошког шаренила како у употреби термина говор, тако и у употреби термина дијалекат. Разгранато лексичкосемантичко поље сродних терминолошких значења основних термина у дијалектологији: дијалекат, наречје, говор осликано је и у репрезентативној речничкој литератури (нпр. РСАНУ). Погледом на одреднице у овом речнику (в. говор - 4.а, б.; дијалекат - 1.; наречје - 1.: изговор - 1.6.) видимо да су изједначени термини говор, дијалекат, наречје и изговор. Ако се зна методологија израде Речника, јасно је да су дефиниције одредница, у овом случају термина, утемељене на прецизно ексцерпираној релевантној литератури и да оне експлицитно осликавају терминолошко стање у досадашњој српској дијалектолошкој науци.

Питања која се тичу српског језика и његових дијалеката у основношколској и средњошколској настави заокупљају пажњу истраживача више деценија. Међутим, досадашња испитивања су углавном указивала на препоруке наставницима како би могли најефикасније организовати наставу српског језика на дијалекатском подручју, на значај локалног говора у изграђивању језичке културе ученика, као и на конкретне модификације наставних начела и реализацију наставних јединица на разуђеним дијалекатским просторима српскога језика (Станић, 1956; Дешић, 1981; Ћупић, 2001; Јањић, 2005; Смиљковић и сар., 2009). Донекле сличан поглед на улогу дијалектологије у наставном процесу имају и истраживачи изван српског језичког простора (Thomas, 1988; Володина, 1993; Repetti, 1996; Kretzschmar, 1999; Kristiansen, 2001), с том значајном разликом што је у испитивањима на тлу Западне Европе акценат стављен на билингвизам и изучавање матерњег језика у мултиетничким срединама.

Усвајање јасне дијалектолошке терминолошке номенклатуре олакшава јаснију диференцијацију односа књижевног језика и његовог дијалекатског 
окружења (уважавањем предложених граматичких категорија према предвиђеним наставним програмима) и свакако унапређује језичку културу ученика. C тим у вези, циљ рада је да се установи у којој мери су ученици основне школе и средњих школа овладали основним дијалектолошким терминима.

\section{МЕТОД}

Узорак. Подаци су прикупљени на пригодном узорку који је обухватио 315 ученика основних школа (136 ученика; 43,1\%), гимназија (97 ученика; $30,7 \%$ ) и средњих стручних школа ( 82 ученика; $26,2 \%)$. У испитивању је учествовало 136 (43,1\%) ученика осмог разреда основне школе, 91 ученик трећег $(29 \%)$ и 88 ученика четвртог $(27,9 \%)$ разреда гимназија и средњих стручних школа (узорак је уједначен према нивоу образовања: основна и средња школа). Ученици похађају основне и средње школе у Београду, Новом Саду, Нишу, Крагујевцу и Крушевцу . У истраживању је учествовало $176(55,8 \%)$ ученица и 139 (44,2\%) ученика (целокупан узорак је уједначен према полу). Посматрајући оцене ученика из српског језика и књижевности у претходној школској години, опажамо да више од половине ученика (66\%) из овог предмета има одличну $(32,7 \%)$ и врло добру (33,3\%) оцену, док трећина ученика има добру (17,8\%) и довољну (16,2\%) оцену. Општи успех свих ученика на крају претходне школске године такође упућује на чињеницу да су у истраживању учествовали ученици који имају високо академско постигнуће, будући да 271 $(86 \%)$ ученик има одличан и врло добар успех $(\mathrm{M}=4.37, \mathrm{SD}=0.802)$.

Инструмент. За потребе овог истраживања конципиран је упитник који је садржао шест питања отвореног типа. Питања су се односила на основне термине (теме) из области дијалектологије српскога језика: дијалекат, наречје, екавски и ијекавски изговор, распрострањеност штокавског наречја, као и указивање на разлике између говорника двају дијалеката: шумадијско-војвођански и призренско-тимочки дијалекат (Питања: 1. У чему се разликују у изговору речи типа недеља: неђеља; песма: пјесма? 2. Ком говору и наречју припадају дати примери? 3. Дефиниши дијалекат. 4. Дефиниши наречје. 5. Ко све говори цтокавским дијалектом и због чега је овај дијалекат именован као штокавски? 6. По чему се разликују говорници Ваљева и Лесковца?). Одговори ученика процењивани су као тачни или као нетачни.

Ток истраживања. Истраживање је реализовано школске 2015/2016. године. Попуњавање упитника било је индивидуално уз надзор испитивача. Време за попуњавање упитника није било ограничено и у просеку је трајало 30 минута. Испитаници су добровољно учествовали у истраживању и гарантована им је анонимност и поверљивост индивидуалних резултата.

Анализа података. У обради података коришћена је дескриптивна статистичка анализа. За проверу постојања повезаности између разреда и оцене 
из српског језика и постигнућа ученика на датом упитнику употребљен је T тест и Пирсонов коефицијент корелације.

\section{РЕЗУЛТАТИ И ДИСКУСИЈА}

Уколико посматрамо успешност ученика и основне и средње школе у вези са питањима датим у упитнику, уочавамо да је све исправне одговоре дало само двоје ученика $(0,63 \%)$, док четвртина $(25,09 \%)$ њих није уопште овладала базичним знањем из области дијалектологије, будући да ни на једно питање није тачно одговорила (Табела 1). Најуспешнији су били ученици осмог разреда (двоје њих), чији је просечан општи успех у претходној школској години одличан и који имају одличну оцену из српског језика.

Табела 1. Број ученика који су (не)тачно одговорили на сва питања у упитнику

\begin{tabular}{|l|c|c|}
\hline & Број ученика & $\%$ \\
\hline Тачно одговорено на сва питања & 2 & 0,63 \\
\hline Нетачно одговорено на сва питања & 79 & 25,09 \\
\hline Одговорено тачно на једно или више питања & 234 & 74,28 \\
\hline Укупно & 315 & 100,0 \\
\hline
\end{tabular}

Овакав резултат донекле не изненађује с обзиром на то да је ово материја која се изучава у осмом разреду, па можемо претпоставити да је то разлог бољег постигнућа ученика основношколског, а не средњошколског узраста. Међутим, налаз може бити и показатељ репродуктивног облика учења ${ }^{2}$ и трансмисије чињеница, односно знања које је предвиђено школским програмом. Стога, не можемо говорити о функционалном познавању основних тема из дијалектологије српскога језика код наших испитаника, чак ни код двоје ученика који нису направили ниједну погрешку одговарајући на постављена питања. На недовољно систематизовано познавање различитих тема из српског језика, његових правила и експлицитне норме код ученика свих нивоа образовања (ученици основношколског и средњошколског узраста, студенти) указују и резултати других истраживања (Зељић, 2004; Јањић и Чутура, 2012;

${ }^{2}$ Репродуктивни облици учења јесу они у којима ученици дословно понављају изложени наставни садржај, некада и без разумевања, механички (Ивић и сар., 2009). 
Драгићевић, 2012). С тим у вези, савремена настава српског језика, превасходно на дијалекатском подручју, попут савременог образовања у целини, требало би да се заснива на активном, проблемском процесу учења и процесу конструкције знања (Halpern, 2003), како ученици не би пасивно примали и памтили информације.

Подаци приказани у Табели 2 упућују на то да је највећи проблем ученицима представљало 2, односно 5. питање: Ком говору и наречју припадају примери недеља: неђеља; песма: пјесма? Ко све говори штокавским дијалектом и због чега је овај дијалекат именован као штокавски? Одговори на прво од двају наведених питања били су непрецизни и ученици су неретко занемаривали граматичко-стилске аспекте формулисања свог објашњења, што је један од показатеља скучених изражајних могућности ученика. Потврду налазимо у следећим примерима: Недеља и песма припадају српском језику, а ијекавииза припада ирногорском; шумадијсковојвођанском наречју, екавииа и источнохерцеговачком, ијекавища; српском говору и екавском и ијекавском наречју; спадају у екавииу и јекавииу; екавски говор. Иако је на питање ко све говори штокавским дијалектом било позитивних одговора (Срби, Црногорци, Бошњаци, Хрвати), било је и следећих појашњења: Говоре јужни Словени; Говоре Војвођани и неки Срби; југословенска група језика. ${ }^{3}$ Међутим, на питање због чега је тај дијалекат именован као штокавски одговори су били уопштени и непрецизни, попут: Добио је назив по што; зове се тако због заменице користе упитну речиу што - што се могло и очекивати с обзиром на чињеницу да су то питање само узгредно донеле, за ову прилику, прегледане основношколске граматике (Ломпар 2010; Добрић и др. 2011; Ћећез-Иљукић и др. 2010).

Табела 2. Број ученика који су (не)тачно одговорили на појединачна питања у упитнику

\begin{tabular}{|l|c|c|c|c|c|c|}
\hline $\begin{array}{l}\text { Број } \\
\text { ученика }\end{array}$ & $\begin{array}{c}1 . \\
\text { питање }\end{array}$ & $\begin{array}{c}2 . \\
\text { питање }\end{array}$ & $\begin{array}{c}3 . \\
\text { питање }\end{array}$ & $\begin{array}{c}4 . \\
\text { питање }\end{array}$ & $\begin{array}{c}5 . \\
\text { питање }\end{array}$ & $\begin{array}{c}6 . \\
\text { итање }\end{array}$ \\
\hline Тачно & 186 & 8 & 126 & 43 & 11 & 105 \\
\hline Нетачно & 129 & 307 & 189 & 272 & 304 & 210 \\
\hline$\%$ & & & & & & \\
\hline Тачно & $59,05 \%$ & $2,54 \%$ & $40,00 \%$ & $13,65 \%$ & $3,49 \%$ & $33,33 \%$ \\
\hline Нетачно & $40,95 \%$ & $97,46 \%$ & $60,00 \%$ & $86,35 \%$ & $96,51 \%$ & $66,67 \%$ \\
\hline
\end{tabular}

${ }^{3}$ Примере наводимо у оригиналу, како су их ученици написали. 
Премда је нешто више од половине ученика умело експлицитно да објасни у чему се разликују у изговору речи типа недеља: неђеља; песма: пјесма (1. питање), било је и одговора који показују да ученици немају адекватно знање нити из дијалектологије, нити из историје српског језика, нити из фонетике и морфологије. С тим у вези, забележили смо следеће примере: Разлика је у морфологији, тако се користи ј у другој речи; Различите су врсте словенских језика; Разликују се у додатном слову ј и акиенту; Разликују се у дијалекту у зависности у којој држави живе људи који их користе. Неспорно је да изложени резултати упућују на то да код ученика преовлађује својеврсни ,језички" осећај уместо знања. Сличан закључак износи и И. Чутура испитујући ставове млађе генерације говорника о српском језику. Чутура истиче да млади, који чине најпрогресивнију групу говорника српског језика, „немају изграђену свест о томе којим језиком говоре у смислу непознавања основних чињеница о сопственом матерњем језику. Базична карактеристика на којој граде своје ставове јесте неинформисаност коју додатно учвршћује незаинтересованост за питања сопственог језичког, националног и културног идентитета" (Чутура, 2012: 105).

На питање По чему се разликују говорници Ваљева и Лесковиа (6. питање), две трећине ученика је исправно одговорило. Међутим, трећина њих је неретко давала илустративне одговоре: Лесковчани имају смешан дијалекат говора. Тако говоре Ђоша и Шпии у серији Породично благо; Имају другачије говорно наречје; По речима у ьиховим језицима који су различито акцентовани; Брзина и нагласак речи и говор. Резултати показују да мање од половине ученика уме да образложи шта је дијалекат, док незнатан број њих (13,65\%) схвата разлику између дијалекта и наречја, односно уме да дефинише наречје. Дакле, ученицима је било прилично тешко да критеријално прецизирају термине дијалекат и наречје и већина је одговорила да су то синонимни термини, што унеколико осликава податке из граматичке литературе. Поглед у резултате оцртава ученичке нејасноће, које произлазе из одсуства критеријума за терминолошко одређење полазне, најбитније чињенице за дефинисање термина наречје - што је био Вуков критеријум поделе српских говора на: ерцеговачко, сремско и славонско наречје, што је и Белић прихватио (Белић, 1999). Уз то, ученицима је најближи термин говор. Они знају да се њихов говор разликује од говора других, па говор поистовећују нужно са дијалектом. Истраживање је указало и на улогу мас-медија у сагледавању говорних и дијалекатских разлика код различитих група говорника, што је у сагласју са резултатима појединих испитивања о утицају средстава масовних комуникација на (не)унапређивање језичке компетенције деце и младих (Livingstone, 1998; Buckingham, 2006).

Сем тога, анализа података указује на то да постоји статистички значајна корелација између оцене из српског језика, општег успеха и тачности одговора које су ученици дали $(\mathrm{r}=0,371 ; \mathrm{r}=0,201)$, што је у сагласју са налазима 
појединих испитивања у којима је показана позитивна корелација између постигнућа у домену језика и школског ангажовања (Van de Gear et al., 2009). Такође, резултати показују да је просечно постигнуће ученика основне школе успешније, односно основци знатно боље познају дијалектолошку терминологију него ученици који похађају средњу школу $(\mathrm{t}=8,31 \mathrm{p}=1,969)$, што се може приписати чињеници да се теме из дијалектологије изучавају управо у осмом разреду, али може упућивати и на то да ученици градиво учи само да би добили, често не и задовољавајућу, оцену и да српски језик постаје још један у низу предмета чијих се садржаја на крају године ученици не сећају. Дакле, управо супротно основном циљу наставе српског језика: ученици би требало да изучавају српски језик, на свим његовим дијалекатским ареалима, да би се њиме на „адекватан начин служили у свакој прилици” (Танасић, 1998: 302).

Због свега наведеног, а посебно због „шаренила” у одговорима ученика, у осветљавању историјата датога проблема потребно је поћи од учења А. Белића, највећег српског лингвисте, и инаугуратора српске дијалектологије као науке. Белић термине дијалекат, наречје, говор не разматра у хијерархијском међуодносу хиперонимије (надређености) и хипонимије (подређености). Белић тек дескриптивно, без експлицитног сучељавања, осветљава значење наведених термина: „Дијалекти не значе неке засебне целине, нека стварна цепања или неко нарочито груписање становништва. Нове језичке црте, које се спонатано јављају у различитим деловима језичке целине, обухватају врло неједнаке просторе и врло се разнолико укрштају. Према груписању тих црта ми говоримо о образовању дијалеката. Отуда је јасно да су изношења црта дијалекатских као особина засебних говорних целина наша фикција, само средство за научну класификацију факата. Иначе су сви дијалекти једног језика повезани врло многим и врло блиским везама и у прошлости и у садашњости" (Белић, 1999: 177-178). Нешто даље, у истом делу, наилазимо на прецизнију дефиницију. „Назив дијалекат” - каже Белић (Белић, 1999: 266) - „схватамо као апстракцију коју научник прави од језика групе становника које сличне језичке црте повезују тешње него остало становништво, не би ли олакшао своје објашњење или боље схватио судбину језика распрострањеног на ширем пространству."

Терминолошка неопредељеност, узајамна замена основних појмова, њихова преклапања и мешања која не допуштају успостављање хијерархијског устројства - резултат је, пре свега, Белићевих схватања самих појмова које покривају дати термини. Како се из претходних цитата види, Белић је ове термине сматрао научним апстракцијама, које служе дијалектологу да се у многотканом повесму говора једног језика обележе оне језичке групе које обједињује више заједничких језичких црта, које на одређеном простору имају више или мање исту усмереност у распростирању и развоју. Појам дијалеката, 
наречја и говора он је разматрао у оквиру који омеђују, с једне стране - језичке ирте, а с друге-језички простор.

Сам је Белић (Белић, 1999: 266) на више места истицао да је појам дијалекта у извесном смислу недостатан: „Данас смо после толико дијалектолошких радова, навикли да правимо све могуће резерве, када говоримо о дијалектима, о развоју језика посматраног у својим говорним облицима, зато што се понекад и пориче и само постојање дијалеката. Често се каже да постоје само језичке црте које се на различит начин шире на неком језичком простору. Те црте су изоглосе које се укрштају његовим подручјима.” У Белићевом одређењу дијалеката, као што видимо, веома је битан појам изоглоса, која представља линију, ,која обележава неку особину или границу до које се употребљава нека реч или облик. Дијалекти проистичу из различитих снопова изоглоса" (Белић, 1999: 266).

Међутим, за Белића појам дијалекта није потпуно неомеђен, ни толико релативан како би се из неких дијалектолошких радова могло закључити. „Не треба узети у целини” - напомиње Белић (Белић, 1999: 266) - „ни стару представу о дијалектима као о потпуно различитим деловима језика на које се један језик дели или који представљају различите, готово независне епохе његовог развоја (...). Извесно је да на територији свих језика има језичких група које имају више заједничких црта него друге; да у једној групи становника или делу земље, постоји слично усмерење развоја неких језичких црта које се губи чим се пређу њихове границе”. Овим Белић настоји да саму дефиницију термина оснажи и критеријално: „У дефинисању различитих дијалеката и њиховом вештачком разграничавању не треба видети случајно или непредвиђено укрштање неколико изоглоса које им дају заједничке карактеристике, већ чињенице које су резултат многих историјских, социолошких, културних и лингвистичких чинилаца који су деловали у истом правцу. На тај начин, иако су дијалекти научне апстракције, њихова вредност није ни пролазна, ни релативна уколико су добро утврђени. Истина, они представљају оквире лингвистичких слика које могу да се промене током времена, али за једно дато време, док ове лингвистичке слике остају без великих промена, они исто тако имају и мање-више стабилан карактер" (Белић, 1999: 266-267).

Белић најчешће дијалектом сматра групу говора (каткад их зове дијалекатски варијетети) која садржи заједничке црте и развија се мање-више у истом смеру. На истом месту синонимизира термине дијалекат и говор, нпр. кадаје реч о ,ластовском дијалекту, који се обично сматра чакавским дијалектом... Многи дијалекти, захваљујући својој архаичности, имају велики значај за историју српског језика (нпр. чакавски говори)" (Белић, 2000: 48). Ово је за Белића опште начело. Пошто оно важи за све новије дијалекатске анализе (језик - дијалекат - наречје - говор), онда не чуди привидна терминолошка 
пометња. Он сваки ниво језика посматра у његовој развојној перспективи, те је стога уведени трочлани терминолошки систем у његовим анализама веома тешко применити. Њихова појмовна одређења свакако укључују један дијахрони ниво анализе, те су узајамно заменљиви зависно од тога шта у конкретном случају узимамо као еталонску скалу према којој одмеравамо домен њихове реализације.

Белић се, говорећи о развоју српскохрватског језика, место назива $c p$ пскохрватски и словеначки служио дијалектолошким терминима: кајкавски, чакавски и штокавски - за које употребљава и назив дијалекат и назив наречје (Белић, 1999: 268). Међутим, подједнако је равноправан и термин говор: штокавски и чакавски говори (Белић, 1999: 270), или множина првог термина: штокавски дијалекти (Белић, 1999: 270). Њих дели на групе дијалеката: староштокавски, средњоштокавски, новоштокавски дијалекати. „Очигледно је да су сви дијалекти једног језика увек подједнако стари и, ако између дијалеката правим старосне разлике, ја само желим да покажем на ком степену развоја је сваки од тих дијалеката остао на заједничкој скали језичких промена у савременом штокавском" (Белић, 1999: 272-276). Новоштокавски дијалекат, нпр., дели се према замени јата на: екавске говоре (источне), икавске говоре (западне), јекавске говоре (јужне). За њих, пак употребљава и називе: јекавски (или икавски) дијалекат, три дијалекатска изговора, три дијалекатске групе итд. Призренско-тимочки назива најархаичнијим екавским наречјем (Белић, 2000: 19): „најархаичнији је тимочко-лужнички говор, особито његов тимочки поддијалекат" (Белић, 1999а: 34).

Белићева терминолошка решења у српској и/или српскохрватској дијалектологији нису у потпуности прихваћена. Дошло је чак до потпуно другачијег хијерархијског статуса пре свега термина дијелекат и наречје, на што указују и Дешић и Шћепановић (Дешић и Шћепановић, 2003: 263-268).

Подизањем наречја на ниво дијалекта, уз рушење већ делимично усаглашеног система основних дијалекатских термина, довело је до напуштања решења које су заступали А. Белић, на српској, и М. Храсте (1956), на хрватској страни. То је произвело право терминолошко шаренило, са низом нових терминолошких непрецизности. Белић-Храстеова терминолошка решења замењена су новим, у многим цртама инкомпатибилним решењима П. Ивића и Д. Брозовића (Брозовић и Ивић, 1988: 7-119). Белићева терминолошка номенклатура није, међутим, могла преко ноћи бити замењена Ивићевом и Брозовићевом, што есплицитно потврђује „признање” А. Пеца у петом издању његовог приручника из дијалектологије. А управо то пето издање омогућава да сагледамо генезу целога проблема. После критике коју на Пецову књигу даје Д. Петровић (Петровић, 1985: 180-194), Пецо (Пецо, 1991: 17) експлицитно наводи: „У нашој стручној литератури неједнако се вреднују појмови 
дијалекат, наречје, говор. Често се дијалекат и наречје јављају као синоними: штокавски дијалекат/ штокавско наречје. Мада би се могла правити подела српскохрватског језичког подручја по схеми: штокавски дијалекат, екавско наречје, шумадијски говори - како је раније било у овом приручнику, ја овде прихватам термин наречје (уместо ранијег дијалекат) за означавање веће говорне целине. То јест ја овде делим српскохрватско језичко подручје на три наречја: штокавско, кајкавско и чакавско наречје".

На истом месту Пецо даје и нелингвистичке разлоге који су условили овакав терминолошки заокрет: „До ове измене долази само због једног разлога: такву поделу налазимо код загребачких језичких стручњака. Да се не би и ту, у овој дијалекатској терминологији, правиле разлике са могућом варијантском обојеношћу, ја прихватам такву поделу и као своју”. А. Пецо је тако избрисао терминолошке дијалекатске српско-хрватске разлике, али их је Д. Брозовић (Брозовић, 1994: 8) након три године продубио до неповрата изјавом: „Мислим да је терминологија типа српскохрватски или хрватскосрпски сада хрватском народу неприхватљива до алергије и то је напросто чињеница. Ми ћемо то у некаквим кабинетским или лингвистичким срединама звати мало другачије, можда средишњи јужнославенски. Али све је то далеко од стварних животних проблема. Не ради се о удаљавању, како је било речено, јер није постајала ни једна фаза ни код Хрвата ни код Срба која би представљала стварно јединство говорнога колектива. То је оно што никад није постојало, то је химера". О овом Брозовићевом (не)јединству говорног колектива може се говорити само ако је критеријум дијалекатска слика да су Хрвати историјски чакавци, а Срби штокавци. Међутим научно релевантне лингвистичке чињенице не подржавају оваква тврђења, мада упозоравају колико је битно чувати сваки детаљ српске лингвистичке терминолошке апаратуре.

Уз терминолошки заокрет Пеца, и научно неутемељена тумачења Д. Брозовића, за нашу тему занимљив је став Д. Петровића: „За означавање наших 'дијалекатских' реалности (стављам ову реч под наводнике да бих јој у контексту који имам на уму дао нетерминолошко значење) морамо рачунати највише на три јасно разграничена нивоа посматрања. Први од њих је говор као јединица 'најнижег' ранга и он представља укупност језичких црта карактеристичних за одређени микропростор по којима се он супротставља другом микропростору, а са њим заједно укључује се у јединицу вишега ранга - дијалекат. Дијалекат, дакле, представља скуп микропростора чији је сваки подскуп појединачно одређен као говор" (Петровић, 1985: 235).

„Ако се, дакле, све 'дијалекатске' реалности могу посматрати на три нивоа (или на четири - ако у круг посматрања уведемо и језик као целину), јасно је да се и за овај трећи ниво морао утврдити посебан термин, а Ивић и Брозовић предложили су да то буде - наречје. Тако су односи међу појавама чврсто разграничени: (1)/говор/ > /група говора/= (2)/дијалекат/ > /група 
дијалеката/ = (3) /наречје/ > [група наречја] = (4) језик... (У овој шеми, на линији између дијалекта и говора, могао би се, по посебним критеријима, наћи и поддијалекат, али у разматрање тога проблема овде се нећу упуштати)" (Петровић, 1985: 236-237).

Јасно је, међутим, да се за одређење наше дијалекатске реалности не може као основни терминолошки критеријум узимати само т е р и т о р и $\mathrm{j}$ (тј. микропростор) а занемарити низ лингвистичких и ванлингвистичких аргумената (Белић, 1999: 266-267), као што се не могу зенемарити научне чињенице које нуди историја питања ове терминолошке недоследности. Тако, поштујући историјски развој српске дијалектолошке мисли у целом комплексу сложеног социокултурног контекста, данас морамо уважити чињеницу да је српски језик темељен на - свом штокавском дијалекту екавског и ијекавског наречја источнохерцеговачких и шумадијско-војвођанских говора. А да су у оквиру истог дијалекта остали као некњижевни старији говори оба наречја.

Белићеву добро утемељену, али не и довољно систематизовану номенклатуру српске дијелектолошке науке јасно је прецизирао Михаило Стевановић (Стевановић, 1975: 11-21) у својој универзитетскиј граматици, која је и данас незаобилазна у било ком озбиљнијем србистичком раду. Ту је и у садржају јасно истакнуто да се западно-јужнословенски простор дели на три дијалекта: штокавски, чакавски и кајкавски, а да се штокавски дијалекат дели на: најстарије штокавске говоре, старије новоштокавске говоре екавског изговора, најмлађе штокавске говоре екавског изговора, па на штокавске ијекавске говоре, у које убраја: старије новоштокавске говоре ијекавског изговора, млађе новоштокавске ијекавске говоре, и на крају на штокавске икавске говоре.

Овакву номенклетуру заступали су и сви професори и наставници тзв. Стевановићеве школе. Већ млађе генерације, ослоњене на терминолошку номенклатуру коју дају Станојчић и Поповић (Станојчић, Поповић, 2011), замењују Стевановићеву терминологију Ивићевом, негде у исто време кад је и Асим Пецо исто урадио. Тако стешњени између нормативних граматика и нормативног речника, и аутори наших граматика лутају склањајући се иза помињаних ауторитета. Тако, на пример, у граматикама за 8. разред основне школе код скоро свих издавача аутори наводе дефиниције из Речника српскога језика Матице српске, које нису прилагођене узрасту, већ су синонимног карактера па само могу унети, као и што уносе, још већу конфузију у поимању наставне јединице.

Прецизну терминолошку номенклатуру, утемељену на српској дијалектолошкој традицији, и посебно Белићевом учењу, у уџбеничкој примени даје Дешић (1980): „Територија коју захвата српскохрватски (хрватскосрпски) језик подељена је на три дијалекта: штокавски, чакавски и кајкавски (73)... Призренско-тимочки говори деле се на три говорна типа: тимочко-лужнич- 
ки, сврлишко-заплањски и призренско-јужноморавски (74)" - мада је она у каснијим уџбеницима и српским граматикама остала без примене јер су се средњошколске граматике српског језика ослониле на поменути заокрет А. Пеца према много ранијој Ивићевој и Брозовићевој „погодби”. Занимљиво је да је и Мразовић (Мразовић, 2009: 43), у уџбенику српскога језика за странце, прецизнија у одређењу датог термина: „За српски језик је карактеристичан штокавски дијалекат. У хрватском језику у целини постоје осим штокавског, још два дијалекта: чакавски и кајкавски”.

\section{ЗАКЉУЧАК}

Резултати нашег истраживања показују да ученици како основне тако и средње школе нису овладали основним знањима из дијалектолошке науке, будући да су о базичним темама из ове области најчешће давали неадекватне, терминолошки непрецизне и произвољне одговоре, који, пре свега, указују на њихову конфузију у вези са дијалектологијом, али и историјом матерњег, српског језика. Из овог закључка произлази потреба да се у школском систему, превасходно на средњошколском нивоу, на другачији начин приђе језичкој проблематици, што се посебно односи на питања у чијој су основи очување идентитета и интегритета српског језика.

Стога, посматрани терминолшки низ језик - дијалекат - наречје - говорни тип - говор - идиолекат не оставља простор забуни, темељи се на српској дијалектолошкој мисли од Вука до Белића и даље, није оптерећен императивом уједначавања и, што је веома важно, сам терминолошки склоп посматра у процесу језичког развоја. Ово се посебно односи на термин говор, који се не може посматрати изоловано мимо саодноса са нужним терминима с којима чини терминосистем. Чињенице показују да је термин говор једино реалија, док су остали термини, како би рекао Белић, научне апстракције настале из потребе прецизнијег презентовања научних факата и тако их и ваља и поимати (Белић, 1999а). Следствено томе, предлог терминолошког низа основних дијалекатских термина, са хиперонимско-хипонимским карактером елемената, морао би, уважавањем научних чињеница, и вредности нуђених аргумената, изгледати овако:

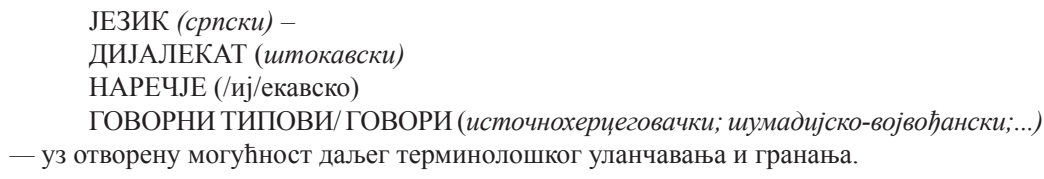

Комплетнији преглед савремене дијалектолошке терминологије и номенклатуре захтева много шири простор, с обзиром на чињеницу да је дијалектолошка визура српских говора скраћена и поремећена, што - како је 
констатовао Ивић (Ивић, 1998: 115) - „,ини ирелевантним појам штокавског наречја. Тај је појам излишан будући да су сви Срби штокавци”.

Распад српскохрватске заједнице на нивоу стандардног или књижевног језика намеће неодложно питање о тој заједници и на нивоу дијалеката, посебно ако имамо у виду да „у сукобу лингвистичких (научних) и социополитичких критеријума за (пре) именовање језика на српскохрватској говорној територији, школа (односно институционализовано образовање) плаћа данак расцепљености између лингвистике и политике" (Чутура, 2012: 112, уп. и: Ковачевић, 2015). Прецизирање и терминолошко одређење новонастале ситуације на нивоу српских народних говора захтева преуређење постојећих и оформљење стабилних, нових термина, а посебно после преименовања српског језика у нове политичке језике под другим именима, намеће неопходност враћања темеља српском језику, а то су, пре свега, итокавски дијалекат са сва три своја наречја - и то, на свим нивоима наставне праксе: основношколске, средњошколске и универзитетске.

\section{ЛИТЕРАТУРА}

Белић 1999: Александар Белић, Историја српског језика, Изабрана дела Александра Белића, седми том. Београд: Завод за уџбенике и наставна средства.

Белић 1999а: Александар Белић, Дијалекти источне и ужне Србије, Изабрана дела Александра Белића, девети том. Београд: Завод за уџбенике и наставна средства.

Белић 2000: Александар Белић, О дијалектима, Изабрана дела Александра Белића, десети том. Београд: Завод за уџбенике и наставна средства.

Брозовић-Ивић 1988: Д. Брозовић, и П. Ивић, Језик, српскохрватски/хрватскосрпски, хрватски или српски, Извадак из Ии издања Енщиклопедије Југославије. Загреб: Југаславенски лексикографски завод „Мирослав Крлежа”.

Buckingham 2006: D. Buckingham, Children and New Media. In: L. A. Lievrouw and S. Livingstone (Eds.) The Handbook of New Media. London: Sage Publications, 75-91.

Van de Gaer-van Damme-de Munter 2009: E. Van de Gaer, Pustjens, H., van Damme, J., \& de Munter, A., School Engagement and Language Achievement: A Longitudinal Study of Gender Differences Across Secondary School. Merrill-Palmer Quarterly, Vol. 55, No. 4, 373-405. 
Володина 1993: М. Н., Национальное и интернацииональное в проиесе терминологической номинации. Москва: Издательство Московского университета.

Дешић 1980: М. Дешић, Савремени српскохрватски језик са акцентологијом. Београд: Завод за уџбенике и наставна средства.

Дешић 1981: М. Дешић, Улога локалних говора у развијању говорне културе ученика. Наш језик, Год. XXV, бр. 3, 162-166.

Дешић-Шћепановић 2003: М. Дешић, и М. Шћепановић, Из дијалекатске терминологије Павла Ивића, Научни састанак слависта у Вукове дане, 32/3. Београд: Међународни славистички центар, 263-268.

Дешић-Шћепановић 2004: М. Дешић, и М. Шћепановић, О (не)уједначености српске дијалектолошке терминологије, Научни састанак слависта у Вукове дане, 33/3. Београд: Међународни славистички центар, 229-235.

Добрић-Штасни-Живковић 2011: Н. Добрић, Г. Штасни, М. Живковић, $C p$ пски језик и језичка култура за осми разред. Београд: Едука.

Драгићевић 2006: Рајна Драгићевић, Култура изражавања у настави српског језика, Иновације у настави, XIX, 2006/1, Београд: Учитељски факултет, 29-35.

Драгићевић 2012: Р. Драгићевић, Лексикологија и граматика у школи. Београд: Учитељски факултет

Зељић 2004: Г. Зељић, Језичка култура у образовању. Педагогија, Год. LIX, бр. 1, 121-127.

Ивић 1998: П. Ивић, Српски дијалекти и њихова класификација, Зборник Матице српске за филологију и лингвистику, XLI/2, 113-132.

Ивић-Пешикан-Антић 2003: И. Ивић, Пешикан, А. Антић, С., Активно учење 2. Београд: Институт за психологију.

Ивић-Пешикан-Антић 2009: И. Пешикан, А., Антић, С., Водич за добар уцбеник: општи стандарди квалитета уибеника. Београд: Завод за уџбенике.

Јањић 2008: М. Јањић, Настава падежа у теорији и пракси. Врање: Учитељски факултет.

Јањић 2008: М. Јањић, Савремена настава говорне културе у основној школи, Нови Сад: Змај.

Јањић-Чутура 2012: М. Јањић, И. Чутура, Простор, време, друштво-сусрети y језику. Јагодина: Педагошки факултет. 
Ковачевић 2012: М. Ковачевић, Статус српског језика на српским универзитетима. у: Б. Димитријевић (ур.), Филологија и универзитет. Ниш: Филозофски факултет, 13-25.

Ковачевић 2014: М. Ковачевић, Српски језик и функционална писменост на универзитету. у: С. Танасић (ур.), Зборник Института за српски језик САНУ II: Српски језик и актуелна питања језичке политике. Београд: Институт за српски језик САНУ, 67-81.

Ковачевић 2015: М. Ковачевић, Српски језик између лингвистике и политике. Бања Лука: Друштво наставника српског језика и књижевности Републике Српске.

Kretzschmar 1999: W. A. Kretzschmar, The Future of Dialectology. Leeds Studies in English, Vol. 30, 271-288.

Kristiansen 2001: T. Kristiansen, Two Standards: One for the Media and One for the School. Language Awareness, Vol. 10, Issue 1, 9-24.

Livingstone 1998: S. Livingstone, Mediated Childhoods: A Comparative Approach to Young People's Changing Media Environment in Europe. European Journal of Communication, Vol. 13, Issue 4), 435-456.

Ломпар 2012: В. Ломпар, Граматика - Српски језик за осми разред основне школе. Београд: Klett.

Маринковић 2009: Ј. Маринковић, Српски језик 1: учбеник за студенте учитељског факултета, Друго, поправљено издање. Врање: Аурора.

Мразовић 2009: П. Мразовић, Граматика српског језика за страние. Сремски Карловци: Издавачка књижарница Зорана Стојановића.

Peco 1991: A. Peco, Pregled srpskohrvatskih dijalekata. Beograd: Naučna knjiga.

Петровачки 1997: Љ. Петровачки, Нека запажања о култури изражава ученика у средњој школи. Језик данас, Год. 3, 7-10.

Петровић 1985: Д. Петровић, Неки проблеми српскохрватске дијалектолошке номенклатуре, Наш језик, XV/3-4, 180-194.

Пешикан 1966: М. Пешикан, О начелима обраде и развијања стручне терминологије, Наш језик, XV/3-4, 180-194.

Правилник о изменама и допунама правилника о плану образовања и васпитања за гимназије и програм образовања и васпитања за II, III и IV разред гимназије; Службени гласник РС - Просветни гласник, бр. 3/1991.

Правилник о изменама и допунама правилника о плану образовања и васпитања за заједничке предмете у стручним школама и програм 
образовања и васпитања за II, III и IV разред; Службени гласник PC - Просветни гласник, бр. 4/1991.

Правилник о наставном програму за осми разред основног образовања и васпитања (2009). Службени гласник РС, Просветни гласник, бр. $72 / 09$.

Правилник о плану образовања и васпитања за гимназију и програму образовања и васпитања за I разред; Службени гласник РC - Просветни гласник, бр. 5/1990.

Repetti 1996: L. Repetti, Teaching about the Other Italian Languages: Dialectology in the Italian Curriculum. Italica, Vol. 73, No. 4, 508-515.

РСАНУ: Речник српскохрватског књижевног и народног језика, 1-18, Српска академија наука и уметности, Институт за српскохрватски језик, Београд 1959-2010.

Смиљковић-Жугић-Стојановић 2009: С. Смиљковић, Р. Жугић, С. Стојановић, Настава српског језика на дијалекатском подручју. Врање: Учитељски факултет.

Станић 1956: М. Станић, Коришћење дијалекатских појединости у настави нашег језика. Књижевност и језик, Год. 3, бр. 8-9, 490-497.

Станојчић 2010: Ж. Станојчић, Граматика српског књижевног језика. Београд: Креативни центар.

Станојчић-Поповић 2011: Ж. Станојчић, Љ. Поповић, Граматика српског језика за гимназије и средње школе. Београд: Завод за уџбенике.

Стевановић 1975: М. Стевановић, Савремени српскохрватски језик I: Увод, фонетика, морфологија. Београд: научна књига.

Танасић 1998: С. Танасић, Настава граматике и говорна култура, у: С. Васић, У. Кисић, М. Даниловић (ур.), Језик и култура говора у образовању, Београд: Институт за педагошка истраживања, Завод за уџбенике и наставна средства, 297-303.

Thomas 1988: A. R. Thomas, Methods in Dialectology: Proceedings of the Sixth International Conference Held At the University College of North Wales. Philadelphia: Multilingual matters LTD.

Ћећез Иљукић-Срдић-Савовић-Вулић 2011: J. Ћећез-Љукић, J. Срдић, С. Савовић и С. Вулић, Дар речи - Граматика за осми разред основне школе. Београд: Логос.

Ћупић 2001: Д. Ћупић, Настава језика и дијалекат. Зборник Института за педагошка истраживања, Год. 33, Бр. 1, 346-350. 
Halpern 2003: D. F. Halpern, Thought and knowledge: An introduction to critical thinking (4th Edition). Mahwah, NJ: Lawrence Erlbaum Associates, Inc. Publishers.

Hraste 1956: M. Hraste, Bibliografija radova iz dijalektologije, antroponimije, toponimije i hidronimije hrvatskoga ili srpskoga jezika. Zagreb: HDZb 1.

Чутура 2012: И. Чутура, Којим језиком друштво (мисли да) говори. у. М. Ковачевић, Д. Бошковић (ур.), Савремено друштво и криза проучавања језика и књижевности. Крагујевац: Филолошкоуметнички факултет, 105-121.

Чутутра-Максимовић-Јањић 2009: И. Чутура, Ј. Максимовић, М. Јањић, Тест основне писмености у селекцији студената - будућих учитеља, y: M. Matti (ур.), Унапређење образовања учитеља и наставника: од селекције до праксе, Јагодина: Педагошки факултет, 337-348. http://www.pefja.kg.ac.rs/preuzimanje/Tempus/Tempus_zbornik_ knjiga_1.pdf

Šimunović 2009: P. Šimunović, Uvod u hrvatsko imenoslovlje. Zagreb: Golden marketing - Tehnička knjiga.

\section{SERBIAN DIALECTOLOGICAL TERMINOLOGY AND TEACHING PRACTICE}

\section{Summary}

It has been ascertained that there is an inconsistency in the use of Serbian dialectological terminology in academic, professional and teaching practice in the Serbian language area as a whole. Solving that problem is a crucial prerequisite for acquiring a lot of dialectological curriculum contents at various levels of education, especially in primary and secondary school instruction. The paper aims at establishing to what extent primary and secondary school pupils have mastered the basic dialectological terms. The research sample is appropriate and consists of 315 primary and secondary school pupils in Belgrade, Novi Sad, Niš, Kragujevac and Kruševac. The results of the survey point to the fact that the confusion from secondary and primary school grammars used so far has created a confusion in the present-day teaching practice. Accordingly, based on the conducted analysis, the paper provides a comment on the existing terminological solutions in Serbian dialectology and their application to the grammatical literature and teaching practice with particular reference to the nomenclatural order: dialect - idiom - speech type - speech - idiolect, and also furnishes a more systematic approach to solving this problem.

Keywords: dialectology, terminology, teaching practice, pupils, dialect, idiom, speech type, speech, idiolect 